\title{
A Case of Cervical Lipoma-related Radiculopathy
}

\author{
Radikülopatiye Neden Olan Servikal Lipom \\ (1) Mustafa Reşorlu, (1) Ozan Karatağ, (1) Canan Akgün Toprak \\ Çanakkale Onsekiz Mart University Faculty of Medicine, Department of Radiology, Çanakkale, Turkey
}

Dear Editor,

A 52 year-old female patient presented to our hospital with numbness and loss of strength in left arm. She mentioned no chronic diseases and that her complaints had continued for 3 to 4 years. Routine hemogram examination, blood glucose level and other routine biochemical parameters were normal. The Doppler ultrasonography applied to eliminate vascular pathologies did not reveal any arterial or venous pathology. An extraforaminal mass lesion at C3-4 level on the left side was
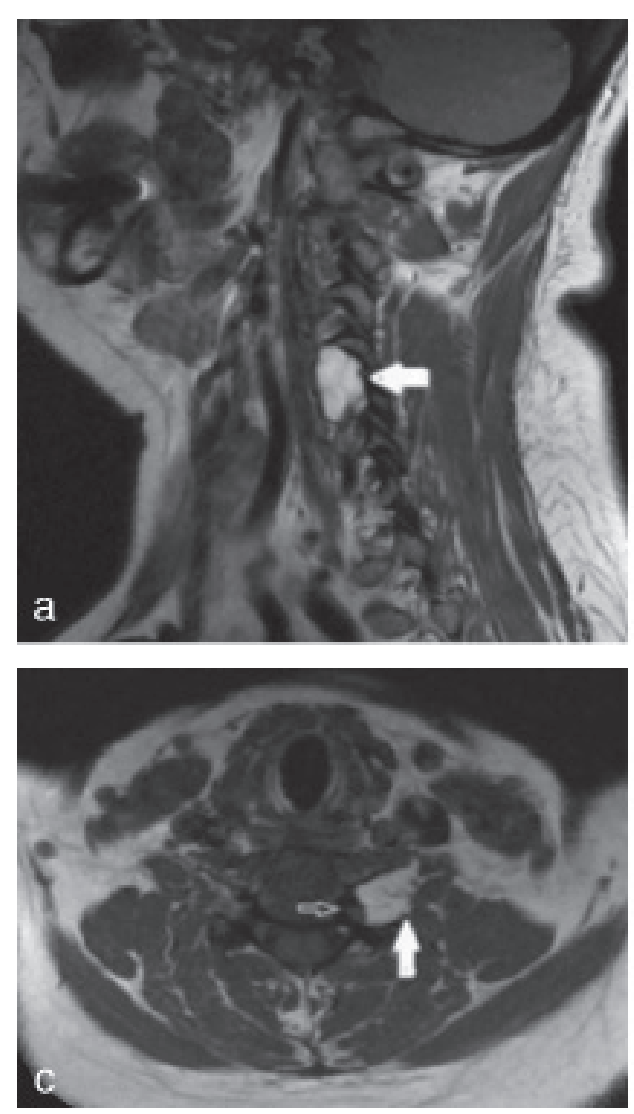

found in the magnetic resonance imaging (MRI) carried out for the prediagnosis of cervical disc hernia. The lesion depicted hyperintense character on T1 and T2 weighted sequences and loss of signal on fat-suppressed sequence. In addition, there was muscle atrophy and nerve root pressure at extraforaminal level (Figure 1).

Lipomas are mesenchymal neoplasms with benign nature originating from mature fat cells. They are rare in cervical region and may cause cosmetic issues if localized superficially, while
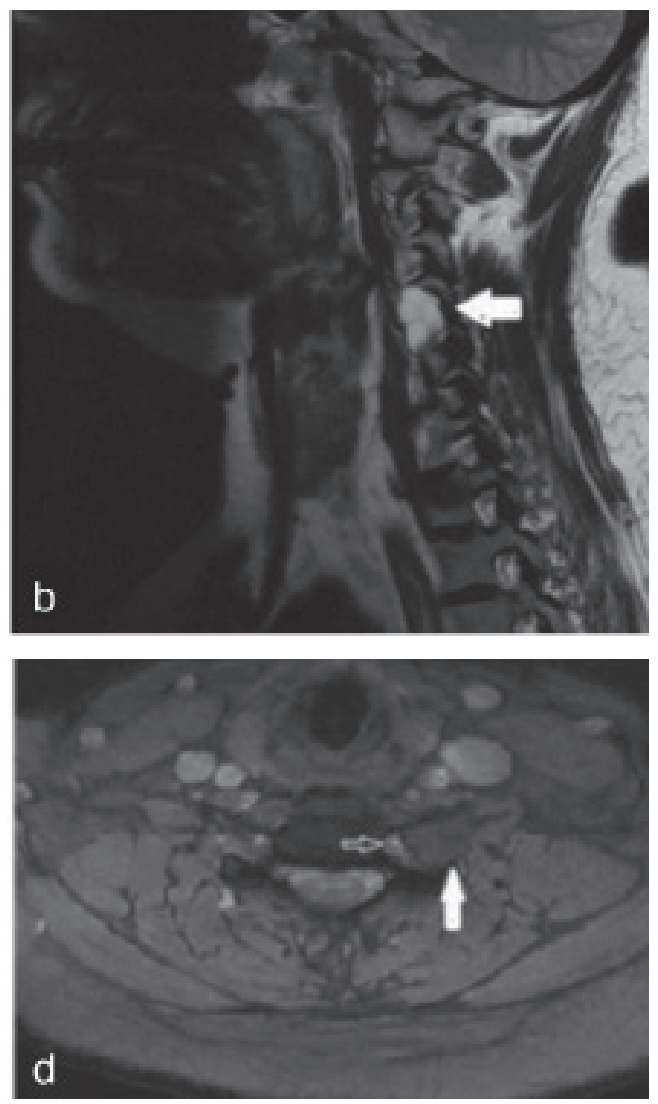

Figure 1. Sagittal T1 (a) and T2 (b) weighted images showing hyperintense lipoma. Hypointensity in the lipoma on a fat-suppressed axial image $(d)$ and compression in the nerve root (c, d black arrow)

Address for Correspondence/Yazışma Adresi: Mustafa Reşorlu MD, Çanakkale Onsekiz Mart University Faculty of Medicine, Department of Radiology, Çanakkale, Turkey Phone: +90 5054548722 E-mail: mustafaresorlu77@gmail.com ORCID ID: orcid.org/0000-0002-2941-8879 Received/Geliş Tarihi: 29.06.2017 Accepted/Kabul Tarihi: 31.05.2018 
deep-seated lipomas may cause pressure on adjacent organ (1) There are various subtypes of lipoma such as simple lipoma, fibrolipoma, atypical lipoma, myxoid lipoma, infiltrating lipoma, angiolipoma and myelolipoma (2). Those with Intermuscular and intramuscular localizations are also known as infiltrating lipomas. Intramuscular infiltrative lipomas originate from adipose tissue adjacent to muscle fibrils and might depict peripherial tissue invasion $(1,2)$. The clear margin character which is typical for benign tumors may not be observed in these tumors. They seldom remain in muscle tissue and may infiltrate into fascia and tendons. Infiltrative lipomas commonly observed in extremities and the abdominal wall muscles are quite rare in the paraspinal muscles. Although its etiology is not well known, however there are a number of suspicious factors. The main ones are trauma, chronic irritation, obesity, genetic and endocrine issues (2). Patients often complain about cosmetic issues or symptoms arising from pressure on adjacent anatomic structures. Asymptomatic cases are diagnosed incidentally via radiological imaging applied for various reasons. Palpable lesions having large sizes have soft consistency and characteristics of slowgrowing mass. No change is anticipated in the soft tissue adjacent to the lesion. Physical examination is limited in non-palpable lesions due to deep-seated localization, and radiological imaging is preferred for diagnosis (3).

The plain radiography finding is radiolucent soft tissue mass in homogeneous fat opacity. Opaque lines of muscle fibers might be seen inside the tumor area. Ultrasonography has similar characteristics with that of superficial lipomas, and is hyperechogenic compared to the muscle tissue. However, it is difficult to detect deep-seated lesions. Despite that the vascularization is not the anticipated finding; some cases may display minimal vascularization (2). Attenuation in computed tomography (CT) similar to fat tissue and negative hounsfield unit value are helpful in diagnosis.

Soft tissue density streaks those can be observed better with $\mathrm{MRI}$ compared to $\mathrm{CT}$ are present in the lesion. It is quite helpful in the diagnosis that the fat tissue has high signal characteristics on T1 and T2 weighted images and hypointens signal on fatsuppressed sequence. Furthermore, interdigitations created by muscle fibers, those are isointense with the muscle tissue, can be detected via MRI $(2,3)$.

Keywords: Lipoma, radiculopathy, magnetic resonance imaging

Anahtar kelimeler: Lipom, radikülopaty, manyetik rezonans görüntüleme

\section{Ethics}

Informed Consent: It was taken.

Peer-review: Externally peer-reviewed.

\section{Authorship Contributions}

Surgical and Medical Practices: M.R., Concept: O.K., C.A.T., Design: M.R., C.A.T., Data Collection or Processing: O.K., C.A.T., Analysis or Interpretation: M.R., O.K., Literature Search: M.R., C.A.T., O.K., Writing: M.R., C.A.T., O.K.

Conflict of Interest: No conflict of interest was declared by the authors.

Financial Disclosure: The authors declared that this study received no financial support.

\section{References}

1. Ozcan C, Görür K, Talas D, Aydin O. Intramuscular benign lipoma of the sternocleidomastoid muscle: a rare cause of neck mass. Eur Arch Otorhinolaryngol 2005;262:148-50.

2. McTighe S, Chernev I. Intramuscular lipoma: a review of the literature. Orthop Rev (Pavia) 2014;6:5618.

3. Ramos-Pascua LR, Guerra-Álvarez OA, Sánchez-Herráez $S$, Izquierdo-García FM, Maderuelo-Fernández JÁ. Intramuscular lipomas: Large and deep benign lumps not to be underestimated. Review of a series of 51 cases. Rev Esp Cir Ortop Traumatol 2013;57:391-7. 